\title{
Nilai Ekonomi Langsung Berbagai Sistem Pengelolaan Hutan Rakyat di Desa Mirring, Kabupaten Polman, Sulawesi Barat
}

\author{
Daud Irundu ${ }^{1 *}$, Andi Arafat ${ }^{1}$, Rahmania $^{2}$ \\ 1Dosen Program Studi Kehutanan, Universitas Sulawesi Barat, Majene \\ ${ }^{2}$ Dosen Program Studi Agribisnis, Universitas Sulawesi Barat, Majene \\ *Email: daud_irundu@unsulbar.ac.id
}

\begin{abstract}
Public forests are land ownership whose management is oriented to timber productivity, but in addition to timber under stands can also be cultivated food crops and environmental services all of which have economic value. Community forest management can provide direct and indirect economic benefits as an alternative source of economic income for the people of Mirring Village, Binuang District, Polman, West Sulawesi. This research aims to find out how much the direct economic value of community forest based on its management system which can then be used as a reference for future forest management plan. The research was conducted from March to December 2017. Data were collected using survey and interview methods, where the observed variables included descriptions of community forests, community forest productivity including timber and non-timber forest products, and local market prices. The analysis is done descriptively quantitative. The result of the research shows the highest economic value is in agroforestry forest management system of Rp.127.962.157, followed by mixed stands and monoculture system of Rp.97.894.958 and Rp.71.728.608, respectively. Products produced by community forests consist of timber and non-timber forest products.
\end{abstract}

Keywords: economic value, forest community, Polman.

\section{PENDAHULUAN}

Hutan rakyat dewasa ini banyak dikelolah tanpa memperhatikan teknik dan sistem silvikultur. Mayoritas hutan rakyat dikelolah dengan sistem monokultur atau campuran, walaupun terdapat beberapa hutan rakyat yang pengelolaannya menggunakan sistem tumpang sari. Kurangnya pemahaman petani hutan terhadap kemampuan lahan yang dapat dioptimalkan pengelolaannya sehingga dapat menjadi sumber penghasilan yang menjajikan untuk kehidupan para petani hutan rakyat. Menurut Simbolon, dkk (2014), Masyarakat pada umumnya hanya mengetahui cara mengambil atau memanfaatkan hasil-hasil hutan berdasarkan pengetahuan mereka sendiri yang telah diwariskan secara turun-temurun dari leluhur mereka, tanpa mengetahui cara yang tepat untuk menjaga kelestarian dan eksistensi hutan. Hal ini juga terjadi pada beberapa pengelolaan hutan rakyat di Sulawesi Barat salah satunya adalah pengelolaan hutan rakyat yang ada di Desa Mirring Kecamatan Binuang Kabupaten Polman.

Secara administrasi Kecamatan Binuang berada di wilayah timur kota Polewali dengan luas \pm

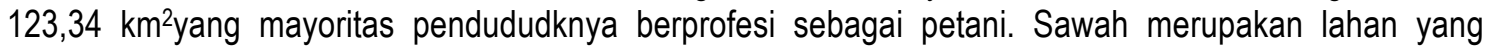
terdapat hampir diseluruh desa di Kecamatan Binuang terkecuali di Desa Mirring. Kehidupan masyarakat di desa ini banyak bergantung pada sumbedaya alam dari dalam hutan termasuk hutan rakyat. Secara umum produksi kayu dari hutan rakyat di Desa Mirring meliputi; jati lokal, jati putih, sengon dan kemiri, Badan Pusat Statistik (2010).

Rendahnya pemahaman masyarakat desa tentang optimalisasi pengelolaan hutan rakyat secara berkelanjutan mengakibatkan banyak masyarakat di Desa Mirring yang masih berada pada garis kemiskinan. Sejauh ini masyarakat di desa ini menanam pohon hanya untuk mempersiapkan bahan baku kontruksi rumah saja. Sehingga sistem tanam, daur dan rotasi tanam tidak ditemukan pada sistem pengelolaan hutan rakyat tersebut. Hal mendasar yang masyarakat tidak pahami adalah nilai ekonomi langsung dari hutan rakyat yang dapat memberikan jaminan pendapatan bila hutan rakyatnya dikelolah dengan baik dan berkesinambungan. Beberapa petani hanya mengetahui nilai ekonomi langsung dari tanaman perkebunan seperti kakao, langsat, durian dan cengkeh. Menurut Sukardi (2017), pendapatan 
petani hutan terbagi atas dua yakni pendapatan dari luar hutan berupa olah lahan perkebunan dan pendapatan dari dalam hutan melalui sistem Agroforestri. Sehingga sejatinya hutan rakyat dapat menjadi solusi permasalahan kemiskinan masyarakat desa melalui pengelolaan hutan rakyat secara optimal berkelanjutan berdasarkan nilai ekonomi maksimal yang dapat diberikan.

Hal menarik yang ada dalam pengelolaan hutan rakyat adalah waktu panen yang masyarakat atau petani hutan rakyat telah ketahui dan meraka dapat mempredikasikannya. Menurut Pratama dkk, (2015) dalam penelitiannya Hutan rakyat selain memiliki hasil hutan kayu juga memiliki hasil hutan bukan kayu, dari kedua jenis komoditi ini masyarakat dapat menetukan waktu panennya berdasarkan musim panen dan berdasarkan kebutuhan. Potensi ini kemudian dapat menjadi dasar pengelolaan hutan rakyat untuk memperoleh nilai ekonomi langsung yang produktif dan berkelanjutan.

Berdasarkan hal tersebut, dipandang penting untuk melakukan penelitian terkait nilai ekonomi hutan rakyat di Kecamatan Binuang, Kabupaten Polewali Mandar Sulawesi Barat. Dimana penelitian ini bertujuan untuk mengetahui seberapa besar nilai ekonomi langsung yang dihasilkan hutan rakyat berdasarkan sistem pengelolaannya di desa Mirring Kabupaten Polewali. Selain itu dengan adanya penelitian ini diharapkan dapat menjadi bahan informasi tentang pengelolaan hutan rakyat dengan optimalisasi manfaat ekonomi secara lestari.

\section{METODOLOGI PENELITIAN}

\subsection{Waktu dan Tempat}

Penelitian ini dilaksanakan pada bulan Agustus sampai dengan Desember Tahun 2017 di Desa Mirring, Kecamatan Binuang, Kabupaten Polewali Mandar, Sulawesi Barat.

\subsection{Alat dan Bahan}

Pada penelitian ini menggunakan beberapa alat antara lain; gps, parang, palu/martil, meteran roll, pita ukur, kamera. Sedangkan bahan yang diguanakan anatara lain: tali plastik, patok, kantong plastik, cat , label , tally sheet, alat tulis menulis.

\subsection{Tahapan Pelaksanaan} meliputi:

Secara umum tahapan pelaksanaan penelitian ini terdiri atas beberapa langkah kegiatan

a. Penentuan responden dengan metode proposive sampling berdasarkan keterwakilan dari masingmasing sistem pengelolaan. Pada masing-masing sistem dipilih 3 responden yang merupakan pengelola lahan.

b. Penentuan posisi, bentuk, ukuran dan jumlah plot. Plot yang digunakan pada penelitian ini berbentuk bujur sangkar dengan ukuran plot $(20 \times 20)$ meter.

c. Pengukuran dan pengamatan variabel. Setelah pembuatan plot dilakukan, maka langkah berikutnya adalah melakukan pengukuran dan pengamatan sistem atau sistem budidaya hutan rakyat, diameter tegakan tingkatan pohon, jenis tanaman, umur tegakan dan jenis HHBK.

d. Mengidentifikasi produksi HHBK melalalui pengukuran dan wawancara dengan pemilik lahan.

e. Mencatat semua hasil pengukuran dan pengamatan.

f. Melakukan dokumentasi kegiatan pengukuran dan pengamatan.

g. Tabulasi dan pengolahan data

Kegiatan tabulasi dan pengolahan data meliputi kegiatan pengimputan data menggunakan komputer untuk pengaman data serta memudahkan dalam kegiatan analisis nantinya. 


\subsection{Analisis Data}

Analisis data dilakukan secara deskriptif kuantitatif meliputi penentuan nilai total, rata-rata, frekuensi dan persentase. Prosedur analisis dilakukan dengan merekapitulasi data identifikasi serta mentabulasikannya. Hasil analisis akan ditampilkan dalam bentuk tabel maupun histogram. Nilai ekonomi langsung kayu dan hasil hutan bukan kayu dapat diketahui menggunakan rumus 1. Menurut Nurfatriani (2006), untuk memperoleh nilai produk hutan dapat melalui pendekatan harga pasar, metode analisis ini digunakan untuk barang atau jasa hutan yang memiliki harga pasar. Data yang diperlukan adalah harga dan jumlah setiap jenis barang/jasa hutan.

$$
\mathrm{Ni}=\mathrm{Jp} \times \mathrm{Hp}
$$

$$
\text { Keterangan: }
$$

$\mathrm{Ni} \quad=$ Nilai Ekomoni suati komoditi

$\mathrm{Jp} \quad=$ Jumlah produksi komoditi per satuan produksinya (kayu, hhbk; $\mathrm{m}^{3}, \mathrm{~kg}$ )

$\mathrm{Hp} \quad=$ Harga Pasar (Rp)

\section{HASIL DAN PEMBAHASAN}

\subsection{Karakteristik Hutan Rakyat}

Hutan rakyat yang terdapat di Desa Mirring, Kabupaten Polman terdiri atas tiga kelompok pengelolaan yang diasumsikan sebagai sistem hutan rakyat. Sistem tersebut meliputi; 1) hutan rakyat yang hanya ditanami jenis tanaman pokok yang sama (monokultur), 2). Hutan rakyat yang ditanami jenis tanaman pokok kehutanan berbeda (campuran), dan 3). Hutan rakyat yang memadukan jenis tanaman pokok kehutanan dengan pertanian (agroforestri).

Berdasarkan hasil analisis diperoleh dominasi relatif komoditas yang dibudidayakan petani pada sistem hutan rakyat desa Mirring adalah jenis jati putih (gmelina arborea) untuk tanaman kehutanan, sedangkan kakao (theobroma cacao) mendominasi pada tanaman pertanian. Dominannya jati putih dibudidayakan petani karena berawal dari bantuan pemerintah terkait pembengunan persemaian jati putih di desa mirring sehingga untuk memperoleh bibitnya, masyarakat tidak terlalu kesulitan. Kakao merupakan salah satu tanaman pertanian yang menjadi primadona di desa Mirring sejak dulu, kerena harga jual yang relatif stabil, dan pemasaran yang tidak terlalu sulit membuat ketertarikan tersendiri pada jenis tanaman pertanian ini sehingga dominasi masih terdapat pada tanaman kakao tersebut.

Jarak tanam menjadi karekteristik tersendiri pada hutan rakyat di Desa Mirring, pada semua sistem pengelolaan hutan rakyat jarak tanamnya sangat bervariasi. Hasil survei jarak tanam terkecil $2 \times 3$ meter dan jarak tanam terbesar $3 \times 4$ meter. Jarak tanam ini juga berlaku pada jenis tanaman pertanian. Namun dalam ketidakteraturan jarak tanam tersebut, terdapat penerapan sistem rotasi yang baik (tebangtanam) berdasarkan daur produksi tanaman pokok kehutanan, yang berdampak pada kesinambungan kegiatan eksploitasi kayu tiap tahunnya.

\subsection{Produktifitas Hutan Rakyat}

Berdasarkan delapan jenis yang terdapat pada hutan rakyat di Desa Mirring, terdapat tiga jenis produk hutan yang dihasilkan. Produk tersebut meliputi; kayu, buah dan tanaman yang menghasilkan keduanya. 


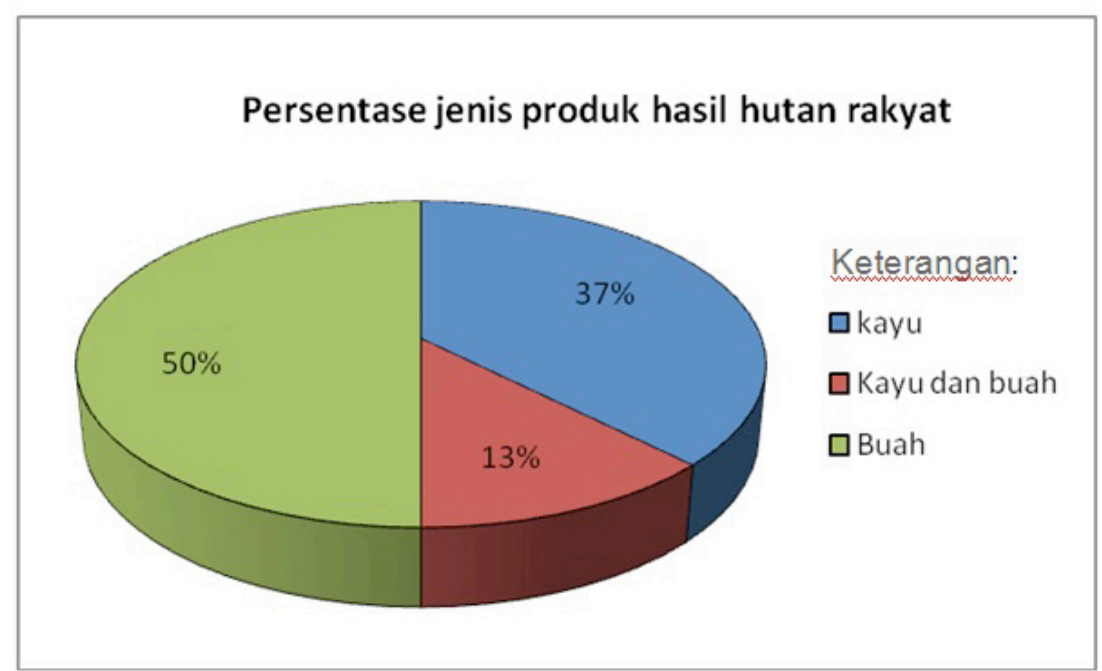

Gambar 1. Persentase produk yang dihasilkan hutan rakyat desa miriing

Persentase produk yang dihasilkan oleh hutan rakyat (Gambar 1.) menunjukan komoditi buah lebih banyak jenisnya dibandingkan komoditi lainnya. Dari delapan jenis tanaman 4 diantaranya menghasilkan buah, tiga menghasilkan produk kayu dan hanya satu jenis tanaman yang menhasilkan produk keduanya. Dominannya jenis produk hutan buah terpadapat pada hutan rakyat sistem agroforestri, dimana pada sistem ini memang mengutamakan hasil hutan bukan kayu yang dapat diproduksi sepanjang tahun. Sedangkan kayu dapat dipanen berdasarkan daur produksi maksimalnya saja yakni 7 sampai dengan 10 tahun. Hal ini yang menjadikan Kecamatan Binuang sebagai salah satu destinasi wisata buah di wilayah sulawesi barat. Menurut Affandi dkk (2017), sistem agroforestri menghasilkan dua kategori hasil yakni produk kehutanan dan produk pertanian. Produk yang dimaksudkan adalah kayu dan hasil hutan bukan kayu (HHBK), sehingga untuk menungjang keberhasilan pengelolaannya perlu mempertimbangkan teknologi yang tepat, sistem pemrosesan serta pemasaran produk HHBKnya.

Produksi kayu hutan rakyat berbeda-beda pada masing-masing sistem pengelolaan. Berdasarkan hasil analisis produktifitas hutan rakyat Desa Mirring dalam memproduksi kayu, seperti terlihat pada Tabel 1, menunjukan produksi kayu terbanyak dihasilkan HR sistem campuran dan paling sedikit dihasilkan oleh HR sistem agroforestri. Produksi kayu diperoleh dari hasil perhitungan volume batang yang telah dikalikan dengan rendemen kayu gergajian sebesar $69 \%$. Terdapat perbedaan yang sangat besar pada masing-masing sistem hutan rakyat, menurut Widiarti dan Prajadinata (2008), bahwa pertumbuhan pohon kayu pada areal kebun campuran dipengaruhi oleh banyak faktor yaitu kerapatan pohon, sistem tanam dan jenis tanaman tumpangsari, teknik silvikultur/budidaya yang diterapkan dan tentunya faktor kondisi lahan. Oleh karena itu sulit menduga volume tegakan kayu per satuan luas lahan pada kebun campuran.

Tabel 1. Produksi kayu pada berbagai jenis dan sistem hutan rakyat (HR)

\begin{tabular}{clccc}
\hline \multirow{2}{*}{ No } & \multirow{2}{*}{ Komoditi } & \multicolumn{3}{c}{ Produksi Kayu pada Sistem HR (m3/tahun) } \\
\cline { 3 - 5 } & & Monokultur & Campuran & Agroforestri \\
\hline 1 & Jati putih & 146,62 & 61,85 & 38,71 \\
2 & Jati lokal & - & 94,56 & - \\
3 & Kemiri & - & 202,83 & - \\
4 & Bitti & - & - & 16,80 \\
\hline Total & & 146,62 & 359,24 & 55,51 \\
\hline
\end{tabular}


Jenis pohon yang diukur kubikasinya pada penelitian ini adalah pohon dengan diameter $>30 \mathrm{~cm}$. Jumlah pohon yang diukur pada setiap plotnya berkisar 2-7 pohon saja. Besarnya volume kayu kemiri disebabkan diameter dan tinggi pohon yang relatif besar dibandingkan jenis lainnya. Diameter terbesar kemiri mencapai 70,38 cm dengan tinggi bebas cabang $11 \mathrm{~m}$. Selain diameter dan tinggi dominasi pohon kemiri juga relatif banyak. Jati putih dominan keberadaannya pada hutan rakyat, namun diameter terbesarnya hanya mencapai $61,78 \mathrm{~cm}$ dan tinggi $12 \mathrm{~m}$. Penggunaanya kayu dari hutan rakyat di Desa Mirring hanya sebagian kecil yang dipasarkan, kayu tersebut lebih banyak digunakan untuk memenuhi kebutuhan kontruksi rumah pribadi para pentani.

Hasil hutan selain kayu merupakan produk yang familiar bernilai ekonomi oleh petani di Desa Mirring. Berdasarkan hasil pengamatan dan pengukuran terdapat lima komoditi yang dihasilkan hutan rakyat yakni buah kemiri, kakao, langsat, rambutan dan mangga. Pengukuran produksi langsat, rambutan, dan mangga dilakukan berdasarkan kondisi buah segar, sedangkan kakao dan kemiri diukur pada kondisi kering udara. Terlihat pada tabel 2. Produksi terbesar terdapat pada buah mangga, besarnya produksi mangga ini karena dalam pengelolaan hutan rakyat banyak dibudidayakan tanaman mangga dengan kondisi pohon yang cukup besar sehingga mampu mengasilkan buah yang cukup banyak. Berbeda dengan tanaman rambutan yang pembudidayaannya hanya sedikit dan sering mengalami kegagalan panen.

Tabel 2. Produksi hasil hutan bukan kayu.

\begin{tabular}{rlrr}
\hline \multirow{2}{*}{ No } & \multicolumn{1}{c}{ Komoditi } & \multicolumn{2}{c}{ Produksi HHBK } \\
\cline { 3 - 4 } & & (satuan pasar /ha/thn) & $(\mathrm{kg} / \mathrm{ha} / \mathrm{thn})$ \\
\hline 1 & Buah kemiri & 500 karung & 20.000 \\
2 & Buah kakao & 4.583 kg & 4.583 \\
3 & Buah langsat & 383 karung & 11.500 \\
4 & Buah rambutan & 58 karung & 1.167 \\
5 & Buah mangga & 1.250 keranjang & 31.250 \\
\hline Total & & & 68.500 \\
\hline
\end{tabular}

Keberadaan komoditi/produk hasil hutan bukan kayu ini hanya diproduksi oleh hutan rakyat sistem agroforestri, sehingga tanaman HHBK seperti kemiri, langsat, rambutan dan mangga dapat dipanen setiap tahun, kecuali kakao yang dapat dipanen sekali seminggu. Berbeda dengan produk kayu yang dipanen berdasarkan masak tebangnya atau daur produksi maksimalnya. Jika diperhatikan produksi kayu pada sistem agroforestri sangatlah sedikit, namun produksi lain dari HHBK dalam hal ini pangan hutan dapat menutupi kebutuhan para petani dalam jangka waktu yang lebih singkat dibandingkan kayu. Menurut Mayrowani dan Ashari (2011), Salah satu alternatif peningkatan produksi lahan adalah dengan sistem ekstensifikasi dengan memanfaatkan lahan kehutanan dengan sistem agroforestry. Dalam menghitung produksi dan pasaran produk ini, petani menggunakan satuan pasar yang telah disepakati bersama. Satuan pasar yang dimaksud adalah perhitungan nilai jual berdasarkan takaran lokal yakni menggunakan hitungan karung, ataupun keranjang. Hanya kakao saja yang satuan pasarnya menggunakan kilogram.

\subsection{Nilai Ekonomi Langsung HR}

Berdasarkan hasil analisis, nilai ekonomi hutan rakyat berdasarkan sistem pengelolaan dan produk yang dihasilkan (Tabel 3.), maka diperoleh total nilai tertinggi pada produk kayu sebesar Rp. 191.169.056 ha/tahun dan total nilai tertinggi berdasarkan sistem pengelolaan hutan rakyat agroforestri Sebesar Rp. 127.962.157 ha/tahun. Penentuan nilai ekonomi pada penelitian ini menggunakan harga lokal pada saat penelitian. Nilai ekonomi langsung yang diperoleh petani hutan rakyat dengan sistem agroforestri ini tergolong sangat tinggi bila dibandingkan dengan hasil penelitian Amin dkk (2017), di 
wilayah Maros, Sulawesi Selatan, yaitu pendapatan rata-rata petani dangan sistem agroforestri sebesar Rp.34.750.000 per tahunnya. Adanya perbedaan ini disebabkan adanya perbedaan komoditi pertanian dan kehutanan yang ditanam dengan asumsi harga pasar yang juga berbeda, dimana Sistem agroforestri yang mengkombinasikan jenis tanaman jati putih dengan beragam tanaman semusim seperti ubi kayu, kacang mete, dan jagung.

Tabel 3. Nilai ekonomi Hutan rakyat berdasarkan produk dan sistem hutan rakyatnya.

\begin{tabular}{ccccc}
\hline \multirow{2}{*}{ No } & \multirow{2}{*}{$\begin{array}{c}\text { Sistem Hutan } \\
\text { rakyat }\end{array}$} & \multicolumn{2}{c}{ Nilai ekonomi (Rp/tahun) } & \multirow{2}{*}{ Total (Rp) } \\
\cline { 3 - 4 } & Monokultur & 71.728 .608 & HHBK & \\
\hline 1 & Campuran & 97.894 .958 & - & 71.728 .608 \\
2 & Agroforestri & 21.545 .490 & - & 97.894 .958 \\
\hline Total (Rp) & 191.169 .056 & 106.416 .667 & 127.962 .157 \\
\hline Rata-rata & 63.723 .019 & 35.472 .222 & 297.585 .723 \\
\hline
\end{tabular}

Tingginya nilai ekonomi hutan rakyat sistem agroforestri disebabkan oleh adanya dua variabel inputan nilai ekonomi yakni kayu dan hasil hutan rakyat bukan kayu. Nilai kayu pada sistem agroforestri tegolong rendah bila dibandingkan dengan sistem lainnya, namun dengan akumulasi nilai dari HHBK, nilai ekonomi sistem ini menjadi sangat besar. Distribusi nilai ekonomi pada sistem agroforestri ini juga cukup baik kerena nilai ekonomi dapat diperoleh setiap bulan, berbeda dengan sistem monokultur dan campuran, nilai ekonominya hanya dapat diperoleh per tahunnya.

Nilai ekonomi langsung kayu dari hutan sepenuhnya tidak menjadi pendapatan masyarakat petani hutan rakyat, kerena banyak hasil kayu yang tidak dipasarkan secara komersil sebaliknya hanya digunakan untuk kebutuhan pribadi. Ketidaktahuan masyarakat dalam kegiatan penatagunaan hasil hutan menjadi faktor utama dalam upaya pemasaran kayu dari hutan rakyat di desa mirring. Menurut Arafat dkk (2017), Pelaksanaan penatausahaan hasil hutan hak di Kabupaten Polewali Mandar tidak berjalan sesuai peraturan yang berlaku, dalam pelaksanaannya, penatausahaan hasil hutan hak masih perlu dikaji dan ditunjang dengan petunjuk pelaksanaan dan petunjuk teknis agar tercapai penyelenggaraan penatausahaan hasil hutan hak yang tertib lancar dan terkendali.

\section{KESIMPULAN DAN SARAN}

\subsection{Kesimpulan}

Berdasarkan hasil penelitian yang merujuk pada tujuan penelitian ini, maka disimpulkan bahwa hutan rakyat di Desa Mirring, Kecamatan Binuang, Kabupaten Polman memiliki tiga sistem pengelolaan hutan rakyat. Nilai ekonomi tertinggi terdapat pada sistem pengelolaan hutan rakyat agroforestri sebesar Rp.127.962.157, diikuti oleh sistem campuran dan monokultur masing-masing sebesar Rp.97.894.958, dan Rp.71.728.608. Produk yang dihasilkan hutan rakyat terdiri atad hasil hutan kayu dan hasil hutan bukan kayu.

\subsection{Saran}

Sebagai bahan informasi yang kompleks perlu dilakukan penelitian, penelitian lanjutan terkait pengelolaan hutan rakyat di Desa Mirring maupun desa-desa lainnya di wilayah Polewali Mandar, Sulawesi Barat. 


\section{UCAPAN TERIMA KASIH}

Terima kasih peneiliti ucapkan kepada Universitas Sulawesi Barat, melalui Lembaga Penelitian dan Penjaminan Mutu yang telah membiayai penelitian ini dari awal hingga di penulisan jurnal ini. Selain itu terima kasih pula kepada Dekan Fakultas pertanian dan Kehutanan Unsulbar serta rekan-rekan dosen yang selalu memberi motofasi dan saran hingga terselesaikannya penelitian ini.

\section{DAFTAR PUSTAKA}

Affandi, O., Zaitunah, A. and Batubara, R. 2017. Potential Economic and Development Prospects of Non Timber Forest Products in Community Agroforestry Land around Sibolangit Tourism Park. Forest and Society (1), 68-77.

Amin, A.S. and Mas' ud, E.I., 2017. Preferensi Masyarakat terhadap Pola Pemanfaatan Lahan Hutan Rakyat di Desa Lekopancing, Kecamatan Tanralili, Kabupaten Maros. Jurnal Hutan dan Masyarakat, 9(2),131-135.

Arafat, A., Yusran, Y., and Sabar, A. 2017. Implementasi Penatausahaan Hasil Hutan Hak di Kabupaten Polewali Mandar Sulawesi Barat. Jurnal Hutan dan Masyarakat, 9(1), 23-29.

Badan Pusat Statistik. 2016. Statistik Kecamatan Binuang. Badan Pusat Statistik Kabupaten Polewali. Sulawesi Barat.

Mayrowani, H., 2011. Pengembangan Agroforestry Untuk Mendukung Ketahanan Pangan Dan Pemberdayaan Petani Sekitar Hutan. In Forum Penelitian Agro Ekonomi, 29(2), 83-98.

Nurfatriani, Fitri. 2006. Konsep Nilai Ekonomi Total dan Metode Penilaian Sumberdaya Hutan. Jurnal Penelitian Sosial dan Ekonomi Kehutanan, 3(1).

Pratama, A.R., Slamet, B.Y., dan Rudi, H . 2015. Pengelolaan hutan rakyat oleh kelompok pemilik hutan rakyat di desa bandar dalam kecamatan sidomulyo kabupaten lampung selatan. Jurnal sylva lestari, 3(2), 99-112.

Simbolon, D.Y.P., Afifuddin, Y. and Latifah, S., 2015. Valuasi Ekonomi Hutan Tele Di Kabupaten Samosir. Peronema Forestry Science Journal, 4(3), 86-94.

Sukardi. 2017. Analisis Pendapatan Masyarakat Desa untuk Kelestarian Hutan Lindung (Studi Hutan Desa Pattaneteang Kabupaten Bantaeng). Jurnal Hutan dan Masyarakat, 9(1), 44-53.

Widiarti, A. and Prajadinata, S., 2008. Karakteristik hutan rakyat sistem kebun campuran. Jurnal Penelitian Hutan dan Konservasi Alam, 5(2), 145-156. 